\title{
FOUR DECADES OF HYDROLOGICAL PROCESS SIMULATION OF THE ITACAIÚNAS RIVER WATERSHED, SOUTHEAST AMAZON
}

\author{
Edivaldo Afonso de Oliveira Serrão ${ }^{1}$ - ORCID: 0000-0003-2376-847X \\ Madson Tavares Silva ${ }^{1}$ - ORCID: 0000-0003-1823-2742 \\ Francisco de Assis Salviano de Sousa ${ }^{1}$ - ORCID: 0000-0002-4085-0785 \\ Aline Maria Meiguins de Lima ${ }^{2}$ - ORCID: 0000-0002-0594-0187 \\ Cleber Assis dos Santos ${ }^{3}$ - ORCID: 0000-0003-3240-7238 \\ Lorena Conceição Paiva de Ataide ${ }^{1}$ - ORCID: 0000-0003-2022-6798 \\ Vicente de Paulo Rodrigues da Silva ${ }^{1}$ - ORCID: 0000-0003-4914-4833 \\ ${ }^{1}$ Universidade Federal de Campina Grande, Unidade Acadêmica de Ciências Atmosféricas, Programa de Pós- \\ Graduação em Meteorologia, Campina Grande, Paraíba, Brasil. \\ E-mail: oliveiraserrao@gmail.com; madson.geotech@gmail.com; fsouza2011@gmail.com; \\ lorenaataide07@gmail.com; vicente.paulo@ufcg.edu.br \\ 2 Universidade Federal do Pará, Instituto de Geociências, Programa de Pós-Graduação em Ciências Ambientais, \\ Belém, Pará, Brasil. \\ E-mail: alinemeiguins@gmail.com \\ ${ }^{3}$ Instituto Nacional de Pesquisas Espaciais, Centro de Ciência do Sistema Terrestre, Pós-graduação em Ciência do \\ Sistema Terrestre, São José dos Campos, São Paulo, Brasil. \\ E-mail: cleberassis.ufpa@gmail.com
}

Received in $16^{\text {th }}$ May 2018

Accepted in $15^{\text {th }}$ May 2019

\begin{abstract}
:
The impacts of anthropogenic degradation are becoming increasingly more evident in the Amazon and are jeopardizing its environmental systems and water resources, particularly in low monitored watersheds. Thus, the use of hydrological models is necessary to gain an understanding of these impacts on Amazonian river systems. The aim of this study was to analyze the simulation of some hydrological processes in the Itacaiúnas River watershed and its relation with human-induced impacts in the Southeast region of the Para state using the Soil and Water Assessment Tool (SWAT) model. SWAT modeling requires several databases, such as relief, land use and land occupation, soil type, and climatic and hydrological variables. These data are input parameters for the SWAT model. The results showed that the hydrological variables in the Amazon tend to follow the seasonal precipitation cycle, with the highest values occurring between January and June and lowest between July and November. It was evident that base and
\end{abstract}

How to cite this article: SERRÃO, E. A. O., SILVA, M. T., SOUA, F. A. S., LIMA, A. M. M., SANTOS, C. A., ATAIDE, L. P. R. S. and SILVA, V. P. R. S. Four Decades of Hydrological Process Simulation of the Itacaiúnas River Watershed, Southeast Amazon. Bulletin of Geodetic Sciences, 25(3): e20190018, 2019. 
lateral flows are responsible for maintaining perennial river flow during the dry season. Regarding anthropogenic actions in the watershed, precipitation, evapotranspiration, and sediment transportation are clearly affected by environmental degradation, as well as by the replacement of forest by grassland and mining activities. The results may assist in public policy including mitigation and adaptation of environmental systems in the region. In addition, they can improve the management of natural resources in the Itacaiúnas River watershed.

Keywords: hydrological modeling; SWAT; southeastern Amazon.

\section{Introduction}

The Amazon basin represents the largest area of tropical forest on Earth, exerting a significant influence on the local and global climate because of the flows of energy and water in the atmosphere. In addition, it plays a major role in carbon sequestration, as well as in the transfer of water vapor to the atmosphere, fundamental to maintaining the forest itself. Moreover, it has high cultural and biological diversity (Stickler et al., 2013). The high rates of precipitation in the Amazon and the large volumes of water flow in rivers are part of the great hydrological cycle in this region that influences other Brazilian ecosystems, such as the Cerrado (Malhi et al., 2008). However, the increase in the deforestation rate in the Amazon jeopardizes its water balance and consequently its environmental systems.

Deforestation reduces evapotranspiration and increases surface flow because of the lower leaf area index, root density, soil depth and higher soil compaction (Scanlon et al., 2007). Because of anthropogenic changes in the Amazon, many studies seek and propose tools to analyze these impacts from many environmental aspects. According to Sahin and Hall (1996), hydrologic modeling is an important tool to understand the hydrological cycle and can assist in the management of water resources in a watershed. These models, when used in forecasting systems, can aid to reduce the vulnerability of the population to natural risks, particularly in the Amazon River basin, where extre, e hydrological events have occurred during recent years, including floods in 2009 and 2012 and droughts in 1998, 2005, and 2010 (Marengo et al., 2008, Chen et al., 2010, Tomasella et al., 2010). Hydrological models can support the understanding and quantification of different Amazonian hydrological processes, such as evapotranspiration, soil water storage, and river hydrodynamics (Trigg et al., 2009).

Several hydrological models have been developed and applied to Brazilian biomes, from simple conceptual bases to the insertion of geographical information systems (SIGs) (Tucci, 2005). Among these, the Soil and Water Assessment Tool (SWAT), developed in 1990, is a hydrological model for large basins (Arnold et al., 1998). SWAT was designed to incorporate numeric- and vector-based input data, enabling the analysis of hydrological processes at a large spatial scale. Its processing is also completed in a continuous time scale, allowing changes in the simulations of land cover and climatic components (Arnold et al., 1998, Arnold and Fohrer, 2005). Therefore, the SWAT model is a mathematical simulation model that is continuous, semi-distributed, deterministic, and physically-based. In other words, it is a model by means of mathematical equations simulating physical processes and their variations in space and time for a specific field of study. 
In Brazil, SWAT has already been applied in the south and southeast parts of the country. However, it is not very well explored in the north and northeast parts, where the majority of watersheds are unmonitored. SWAT has the advantage of dealing with lack of hydro-climatologic data (Silva et al., 2015, 2016, 2017a, 2017b). Based on the aforementioned information, the objective of this study was to simulate some hydrological processes in the Itacaiúnas River watershed and to analyze their relationship with anthropogenic impacts in the southeast region of the Para state, using the SWAT model. The Itacaiúnas River watershed was chosen to develop this study because it is not well monitored and it has high importance for the region.

\subsection{Study area}

The studied area embraces the Itacaiúnas River watershed in the southeast region of the Pará state. According to the Agência Nacional das Águas (ANA), the Itacaiúnas river watershed (Figure 1 ) is classified as Order 3, according to the Otto Pfafstetter system (NCWR Resolution No. $30 / 2002$ ), and has an area of 42,000 $\mathrm{km}^{2}$. This basin averages $2200 \mathrm{~mm}$ of mean annual rainfall and the mean annual average temperature is $30^{\circ} \mathrm{C}$. It has a tropical monsoon climate, according to the Köppen climate classification.

The Itacaiúnas River rises in Seringa mountain, in the municipality of Água Azul do Norte, and is formed primarily by the junction of the D'Água Preta and Azul rivers. Its mouth is on the west bank of the Tocantins River, in the area of Marabá City, and presents a fairly high level of deforestation, being in the region denominated the "arc of deforestation," with approximately $62 \%$ of all its area deforested, according to the Monitoramento do Desmatamento na Amazônia Legal por Satélite (PRODES project, 2012). It is among the watersheds whose water flows to the Tucuruí hydroelectric power plant, this area is of the ultmost importance to the economic and social development of Brazil.

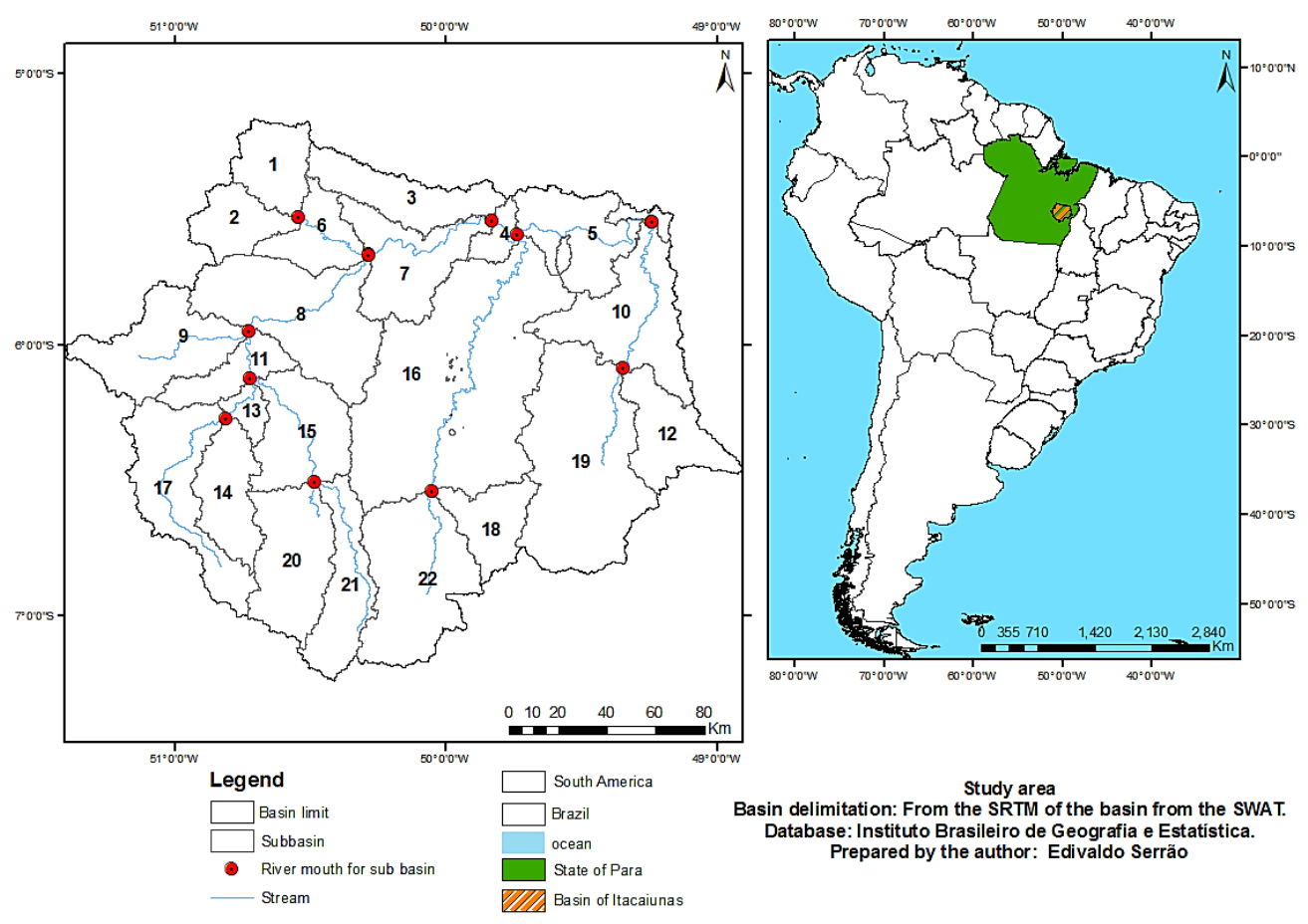

Figure 1: Watershed area of the Itacaiúnas River from the digital elevation model (DEM) of the SWAT model. 


\section{Data and Methods}

\subsection{SWAT modeling stages}

Table 1 presents the procedures adopted and considered as a reference base as follows: Arnold et al. (1998), Machado (2003), Winchel et al. (2013), Arnold et al. (2012), Neitsch et al. (2011), Wagener (2011), Nunes (2012) and Schuol (2008). This presents an integration interface in a Geographic Information System (GIS) enabling a dynamic interaction with the use of remote sensing and GIS, and can be applied to hydrology, hydrometeorology, and hydrogeology.

Table 1. Criteria adopted by SWAT.

\begin{tabular}{|c|c|}
\hline Parameter & Description/Equation \\
\hline $\begin{array}{l}\text { (a) Runoff (Neitsch et al., } 2005 \text { and } \\
\text { Zhang et al., 2013): the estimate of } \\
\text { runoff is conducted by the Method } \\
\text { of the Curve Number (CN), } \\
\text { proposed by the Soil Conservation } \\
\text { Service (SCS). The daily-based CN } \\
\text { factor was determined using the } \\
\text { SWAT model, ranging from } 1 \text { to } \\
\text { 100, where } 1 \text { represents a } \\
\text { completely permeable soil and } 100 \\
\text { a waterproof soil. }\end{array}$ & $\begin{array}{l}\qquad \mathrm{Q}_{\text {sup }}=\frac{(\mathrm{P}-0,2 \mathrm{~S})^{2}}{\mathrm{P}+0,8 \mathrm{~S})}, \mathrm{P}>0,2 \mathrm{~S} ; \\
\quad \mathrm{Q}_{\text {sup }}=0, \mathrm{P} \leq 0,2 \mathrm{~S} \\
\mathrm{~S}=25,4\left(\frac{1000}{\mathrm{CN}}-10\right) \\
\mathrm{Q}_{\text {sup }}=\text { daily runoff }(\mathrm{mm}) ; \mathrm{P}=\text { daily precipitation }(\mathrm{mm}) ; \text { and } \mathrm{S}= \\
\text { retention parameter. }\end{array}$ \\
\hline $\begin{array}{l}\text { Soil erosion as proposed by the } \\
\text { Modified Universal Soil Loss } \\
\text { Equation (MEUPS) (Chaves, 1991, } \\
\text { Chaves and Piau, 2008): this works } \\
\text { with the runoff to simulate erosion } \\
\text { and sediment transport. The K, LS, } \\
\text { C, and P factors are relative to the } \\
\text { digital model, and Qsup and qpico } \\
\text { are associated with the definition of } \\
\text { the runoff from the CN model. }\end{array}$ & 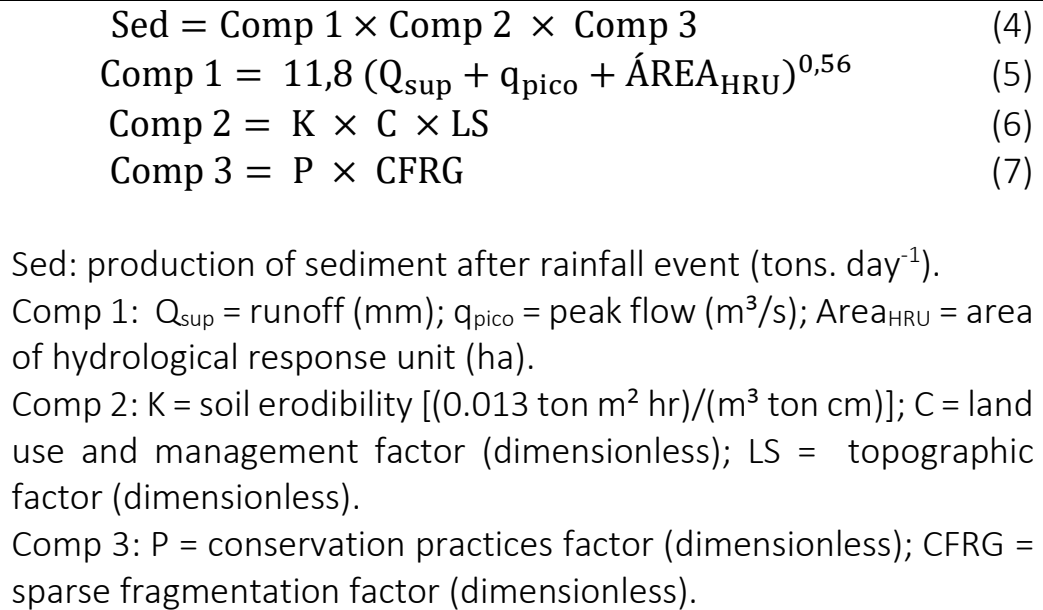 \\
\hline $\begin{array}{l}\text { Climatic data: Precipitation, wind } \\
\text { speed, solar radiation, relative } \\
\text { humidity. }\end{array}$ & $\begin{array}{l}\text { These were extracted from the Climate Forecast System Reanalysis } \\
\text { (CFSR) database from } 1979 \text { to } 2014 \text {, available through the National } \\
\text { Centers for Environmental Prediction (NCEP). Data from a ground } \\
\text { station (municipality of Marabá, } 5.36^{\circ} \text { south latitude; } 49.13^{\circ} \text { west } \\
\text { longitude) belonging to the National Institute of Meteorology } \\
\text { (INMET) during the period from } 1973 \text { to } 2013 \text { were used as the } \\
\text { reference climatic station. }\end{array}$ \\
\hline
\end{tabular}


Table 1. Cont.

\begin{tabular}{l|l}
\hline \multicolumn{1}{c|}{ Parameter } & \multicolumn{1}{c}{ Description/Equation } \\
\hline \multirow{3}{*}{ River flow } & $\begin{array}{l}\text { The data cover the flow measuring station in the Fazenda Alegria } \\
\text { (code 291000), ANA's monitoring network from the period } 1969 \text { to } \\
\text { 2017. }\end{array}$ \\
\hline \multirow{5}{*}{ Land Use } & $\begin{array}{l}\text { Digital elevation model generated from a SRTM image. These data } \\
\text { are in the } 30 \mathrm{~m} \times 30-\mathrm{m} \text { resolution and in the WGS-84 datum. For } \\
\text { this study, we used 22 scenes. }\end{array}$ \\
\hline $\begin{array}{l}\text { Land use data refers to the TerraClass project, which is the result of } \\
\text { a partnership between the National Institute of Space Research } \\
\text { (INPE/CRA), Embrapa Amazônia Oriental and Embrapa Informática } \\
\text { Agropecuária. These data are from the Landsat-5 and Landsat-8 } \\
\text { satellites (Thematic Mapper and Operational Land Imager sensors) } \\
\text { and are in the geographical projection system (latitude and } \\
\text { longitude) and SAD69 geodetic reference system. The TerraClass } \\
\text { 2014 product was used for the study in question. }\end{array}$ \\
\hline Trend test & $\begin{array}{l}\text { We used the Mann-Kendall trend test and the Monte Carlos test of } \\
\text { homogeneity available in the XLSTAT software }\end{array}$ \\
\hline
\end{tabular}

\subsection{Calibration, validation, and statistical analysis}

For calibration of the model, we used the SWAT-CUP 5.0 software, applying the method of calibrating SUFI2. For validation of the results, we used the statistical indexes recommended by the International Precipitation Working Group (IPWG) and described by Liu et al. (2013) and replicated by Adam and Vecchia (2011) and Serrão et al. (2016). Thus, five statistical indexes were used: the Pearson correlation coefficient $(r)$, the coefficient of determination $\left(r^{2}\right)$, the NashSutcliffe efficiency coefficient (NS), the concordance index (CI) based on Willmott (1985), Hallak and Pereira Filho (2011), and Santos et al. (2011) and the quality coefficient (U) (Theil, 1966) for qualitative analysis. The following equations were used: 
Table 2. Statistical indexes used to validate the SWAT.

\begin{tabular}{|c|c|c|}
\hline \multicolumn{2}{|l|}{ Equation } & Description \\
\hline$R=\frac{\sum(X-\bar{X}) \cdot(Y-\bar{Y})}{\sqrt{\sum(X-\bar{X})^{2} \cdot \sum(Y-\bar{Y})^{2}}}$ & (8) & $\begin{array}{l}\text { Pearson's correlation }(\mathrm{R}) \text { : This } \\
\text { coefficient takes on values between }-1 \\
\text { and } 1 \text {. Correlation } 1 \text { refers to perfect } \\
\text { positive and correlation - } 1 \text { refers to } \\
\text { perfect negative. }\end{array}$ \\
\hline$R^{2}=\frac{\sum_{i=1}^{n}\left(\widehat{Y_{I}}-\bar{Y}\right)^{2}}{\sum_{i=1}^{n}\left(Y_{I}-\bar{Y}\right)^{2}}$ & (9) & $\begin{array}{l}\text { Determination } \\
\left(\mathrm{R}^{2}\right): \sum_{i=1}^{n}\left(\widehat{Y}_{I}-\bar{Y}\right)^{2} \text { is the variation of } \\
\text { the dependent variable, and } \sum_{i=1}^{n}\left(Y_{I}-\right. \\
\bar{Y})^{2} \text { is the variation of the independent } \\
\text { variable. }\end{array}$ \\
\hline$N S=1-\frac{\sum_{i=1}^{n}\left(\text { Streamflow }_{E S T}-\text { Streamflow }_{O B S}\right)^{2}}{\sum_{i=1}^{n}\left(\text { Streamflow }_{O B S}-\overline{\text { Streamflow }}_{O B S}\right)^{2}}$ & (10) & $\begin{array}{l}\text { The Nash-Sutcliffe (NS) efficiency } \\
\text { coefficient can range from infinite } \\
\text { negative to } 1 \text {, with a value of } 1 \text { as } \\
\text { indicative of a perfect adjustment. }\end{array}$ \\
\hline $\begin{array}{l}C=1- \\
\frac{\sum_{i=1}^{n}\left(\text { Streamflow }_{E S T}-\text { Streamflow }_{O B S}\right)^{2}}{\sum_{i=1}^{n}\left(\mid \text { Streamflow }_{E S T}-\overline{\text { Streamflow }}_{O B S}|+| \text { Streamflow }_{O B S}-\overline{\text { Stre }}^{-}\right.}\end{array}$ & $\begin{array}{r}\frac{}{B S S \mid)^{2}} \\
(11)\end{array}$ & $\begin{array}{l}\text { Willmott's concordance index }(\mathrm{Cl}) \\
\text { ranges from zero to one, when zero } \\
\text { means no agreement, and one means } \\
\text { perfect agreement. }\end{array}$ \\
\hline$U=\sqrt{\frac{\sum_{i=1}^{n}\left(\text { Streamflow }_{E S T}-\text { Streamflow }_{\text {obs }}\right)^{2}}{\left(\sum_{i=1}^{n}\left(\text { Streamflow }_{\text {obs }}\right)^{2}\right.}}$ & (12) & $\begin{array}{l}U \text { coefficient (Theil): } U>1 \text { is } \\
\text { overestimating the real. } U<1 \text { is } \\
\text { underestimating the real. } U \cong 0 \text { is the } \\
\text { better result. }\end{array}$ \\
\hline $\operatorname{ERRV}(\%)=100 \cdot \frac{\sum_{i=1}^{n} P_{S W A T}-P_{I N M E T}}{\sum_{i=1}^{n} P_{I N M E T}}$ & (13) & $\begin{array}{l}\text { Relative Error of Precipitated Volume } \\
\text { (REPV): in percentage, it refers - to how } \\
\text { much the measured data are being } \\
\text { underestimated }(0<) \text { or overestimated } \\
(>0) \text { by the estimated data. }\end{array}$ \\
\hline
\end{tabular}

\section{Results and Discussion}

The relationship between estimated precipitation modelled by SWAT and precipitation observed at the Marabá station, in addition to the validation, is shown in Figure 2. Notably, the estimated precipitation data are consistent with the observed precipitation of INMET 


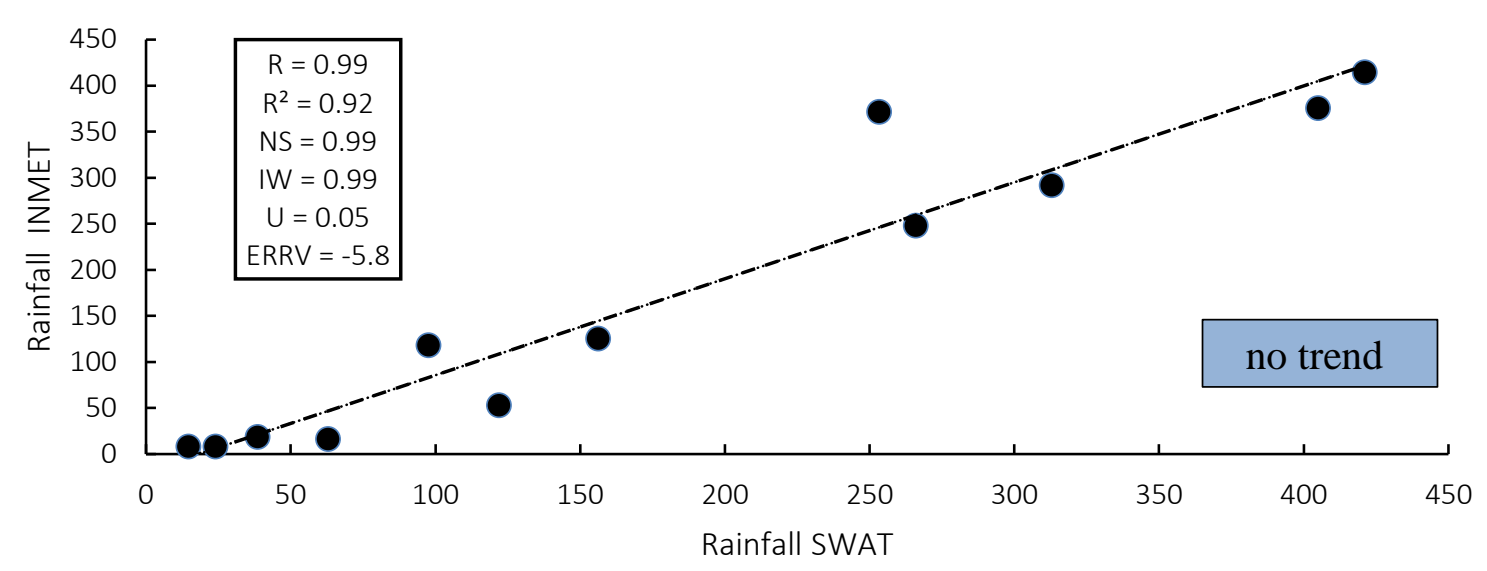

Figure 2. Relation between the monthly average estimated precipitation (SWAT) and observed (INMET) in the Itacaiúnas River watershed and its validation.

By analyzing the statistical indexes used for validation, it is understood that all obtained an excellent performance in validating the Itacaiúnas River basin precipitation. The correlation coefficients were greater than 0.90 as was the efficiency coefficient of NS (0.99). The index of concordance of Willmott indicated 0.99 agreement between the estimated and measured data, and the index $U$ of Theil presented a qualitative relationship overestimate of 0.05 . The relative error of precipitate volume indicated a percentage of underestimating between the simulated and measured data of approximately $5.8 \%$. when the Mann-Kendall test was applied, the series showed no tendency.

\subsection{Calibration of the SWAT model}

In the calibration of SWAT, the SUFI2 method was used in the SWAT-CUP. For the 41 years of hydrological modeling (1969-2010), the calibration was used for five years (2010 to 2015) to calibrate the model. Table 3 shows the parameters that were calibrated in SWAT-CUP. After calibration of the SWAT model, it was again photographed using new parameters and new results for hydrological variables were obtained. The parameters shown in Table 3 represent difficult variable measurement. Moreover, there is limited information available regarding these variables for river basins in Brazil, mainly in the Amazonian Basin. 
Table 3. Parameters used in the calibration of the SWAT model with their variations

\begin{tabular}{cccc}
\hline Ranking & Parameter & Description & Range \\
\hline 1 & Lat_Time & Time required for the return of the lateral flow (days) & 0 a 180 \\
\hline 2 & Esco & Compensation factor of evaporation rate of water in the soil & 0 a 1 \\
\hline 3 & Gwqmin & Limit level of the water in the shallow aquifer for the occurrence of base & 0 a 5.000 \\
& flow (mm) & 0 a 1.000 \\
\hline 4 & Revapmn & Limit depth of water in the soil to the occurrence of the rise of water in & \\
\hline 5 & Alpha_BF & the unsaturated zone (mm) & 0 a 1 \\
\hline 7 & Gw_delay & Interval of time required for recharging the aquifer (days) & 0 a 500 \\
\hline 8 & SURLANG & Retardation coefficient of runoff direct (days) & 35 a 90 \\
\hline
\end{tabular}

\subsection{Analysis of slope and land use}

It is noticeable that the south and the central portion of the basin present highest slopes with a maximum of 66 degrees. These are followed by the flat areas in the south portion of the basin, heading downstream along the Itacaiúnas, with 20 degrees of slope (Figure 3). The catchment area of the Itacaiúnas River has varied slopes resulting from various altitudes in the basin, and this increases the likelihood of erosional processes and siltation of rivers.

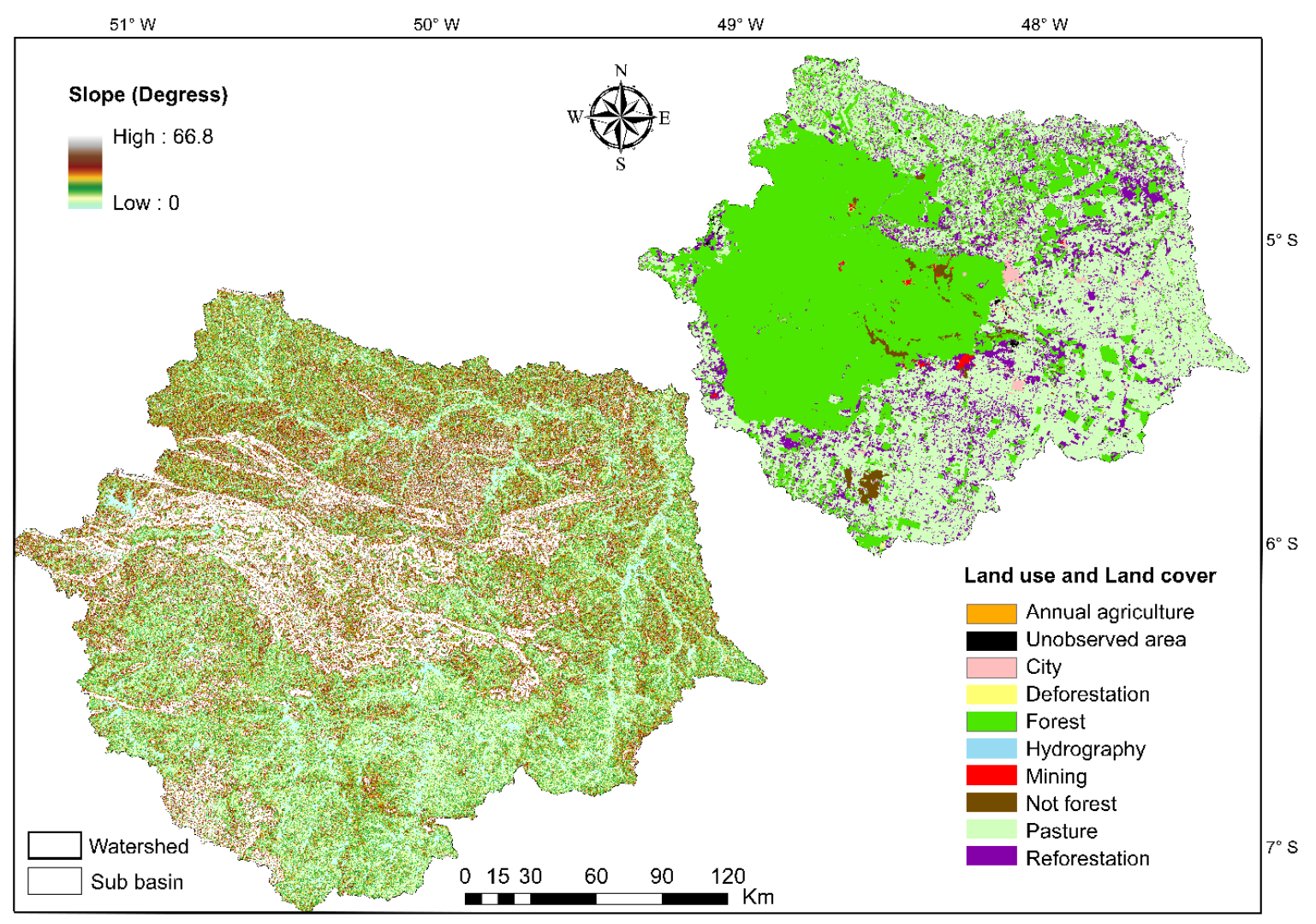

Figure 3. Slope, land use and land cover of the Itacaiúnas River basin 
As shown in Figure 3, 43\% of the basin is composed of native Amazonian forest area (is a conservation unit, of the Carajás National Forest), and $41 \%$ of the basin consists of pasture, followed by reforestation (11\%), mining $(0.35 \%)$ and urban areas $(0.57 \%)$. The basin is quite heterogenous with different types of soil use and occupation, within the catchment area of the Itacaiúnas River. Within the large area of forest are the areas of preservation. Notably, within the areas of mineral extraction there is deforestation, increasing environmental degradation and endangering the fauna, flora, and entire energy and water balance.

\subsection{Hydrological simulation (precipitation and runoff)}

The distribution of the rainfall and consequently the runoff by sub-basin of the Itacaiunas River is shown in Figure 4. The annual mean rainfall is higher in the central and western portions of the basin (between 1,990 $\mathrm{mm}$ and 2,216 $\mathrm{mm}$ ) and it is lower in the southern portion of the basin. This pattern is related whit the displacement (north - south) of the Inter Tropical Convergence Zone (ITCZ), together whit South Atlantic Convergence Zone (SACZ), and to the regional atmospheric circulation regime, as mesoscale systems. Sub basin 20 presented the lowest level of annual mean precipitation, with $1,500 \mathrm{~mm}$.

The Amazon rainforest, through vegetation, has a strong influence on evapotranspiration processes and, consequently, on the hydrological cycle, besides contributing to the interception of rainfall and reduction of the surface runoff process. However, this dynamic is affected by several meteorological variables and the physical factors of the basin (Alves and Pérez-Cabello, 2017).

The spatial distribution of the surface runoff is similar to rainfall. The sub-basin with the highest level of rainfall resulted in highest levels of runoff, and the sub-basins 13 and 14 had the lowest runoff. This is maybe by the land use and occupation in the basin, as shown in Figure 3, where it is clear that the sub-basin has various types of land use and is dominated by Neossolo flúvico, resulting in a higher infiltration and lower runoff. The largest runoff is in sub-basins 1, 3, 5, and 16 with more than $831 \mathrm{~mm}$ and the smallest runoff are in the range of $382 \mathrm{~mm}$ to $417 \mathrm{~mm}$ in subbasins 13 and 14, respectively. 


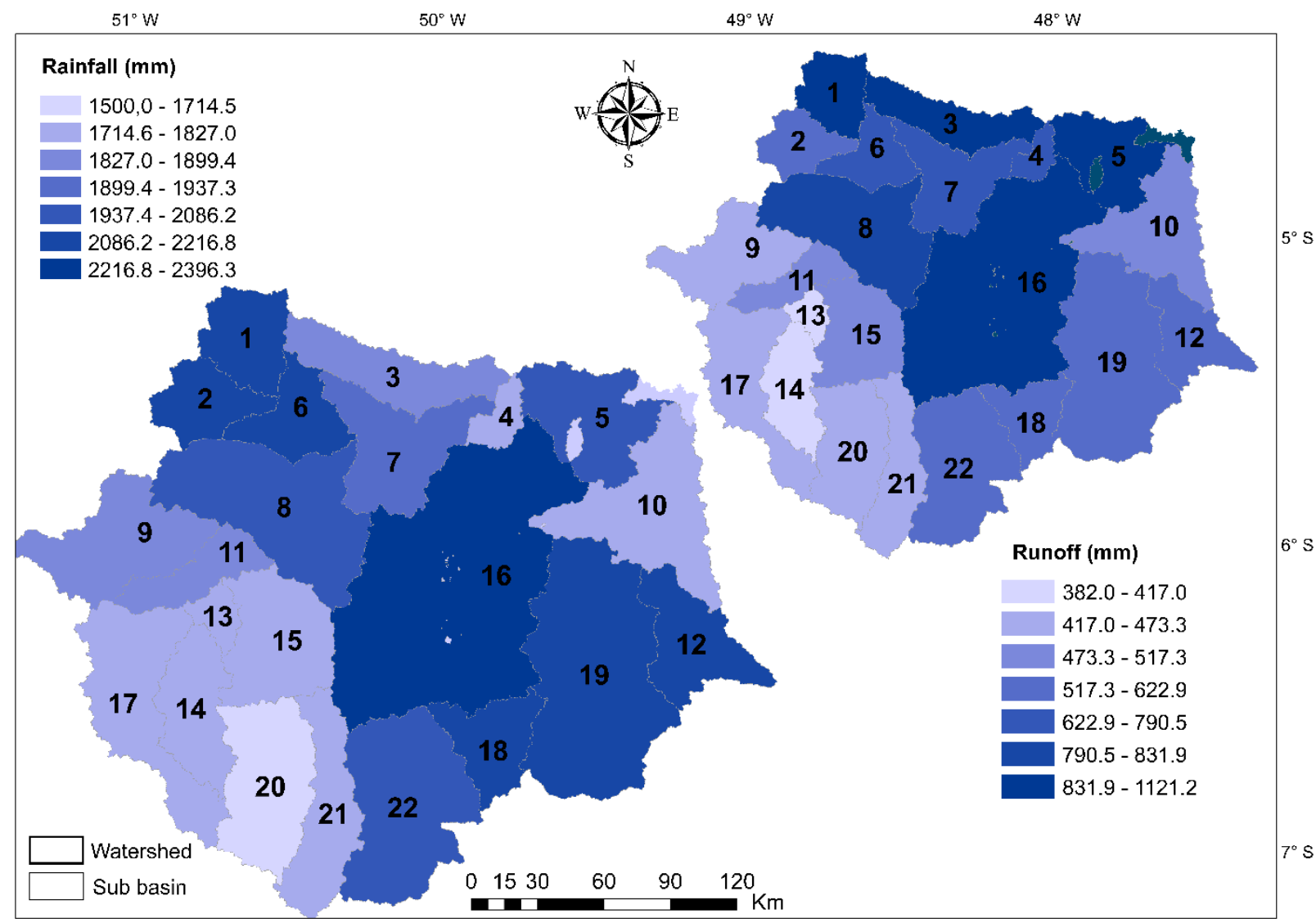

Figure 4. Spatial distribution of precipitation and surface runoff by sub-basin.

\subsection{Hydrological simulation (runoff and sediment transport)}

It is clear that the surface runoff is directly dependent on the rainfall and physical factors of the basin (slope, land, and land use), and each of these variables influence the surface runoff. In its movement towards the exit of a river basin, the intercepted water flows over the rocks and the lands that form or cover the slopes and drainage network gutters (Tucci, 2005). And these obstacles, and the slope, determine the speed of runoff. (Tucci, 2009).

The surface runoff and the yield of sediments depend on the rain and the physical factors of the basin, as shown in Figure 5. It is clear that the sub-basins 8, 11, 13, 14, and 15 are the sub-basins with less yield of sediments ( 0.3 to $0.7 \mathrm{t}^{\text {. ha-1 }}$. year ${ }^{-1}$ ), and they are the sub-basins with the lowest rainfall and runoff. Sub-basins 7 and 4 are the ones that carry considerable sediment and show the highest values of rainfall and runoff. They are sub-basins with red-yellow latosol and high dynamics of land use, with reforestation, cities, woods, pasture, and agriculture. When evaluating land cover and land use changes in Rift Valley, Kenya, using the SWAT model, Baker and Miller (2013) showed that land use changes resulted in the corresponding increase in surface runoff, yield sediment and decrease in groundwater recharge. 


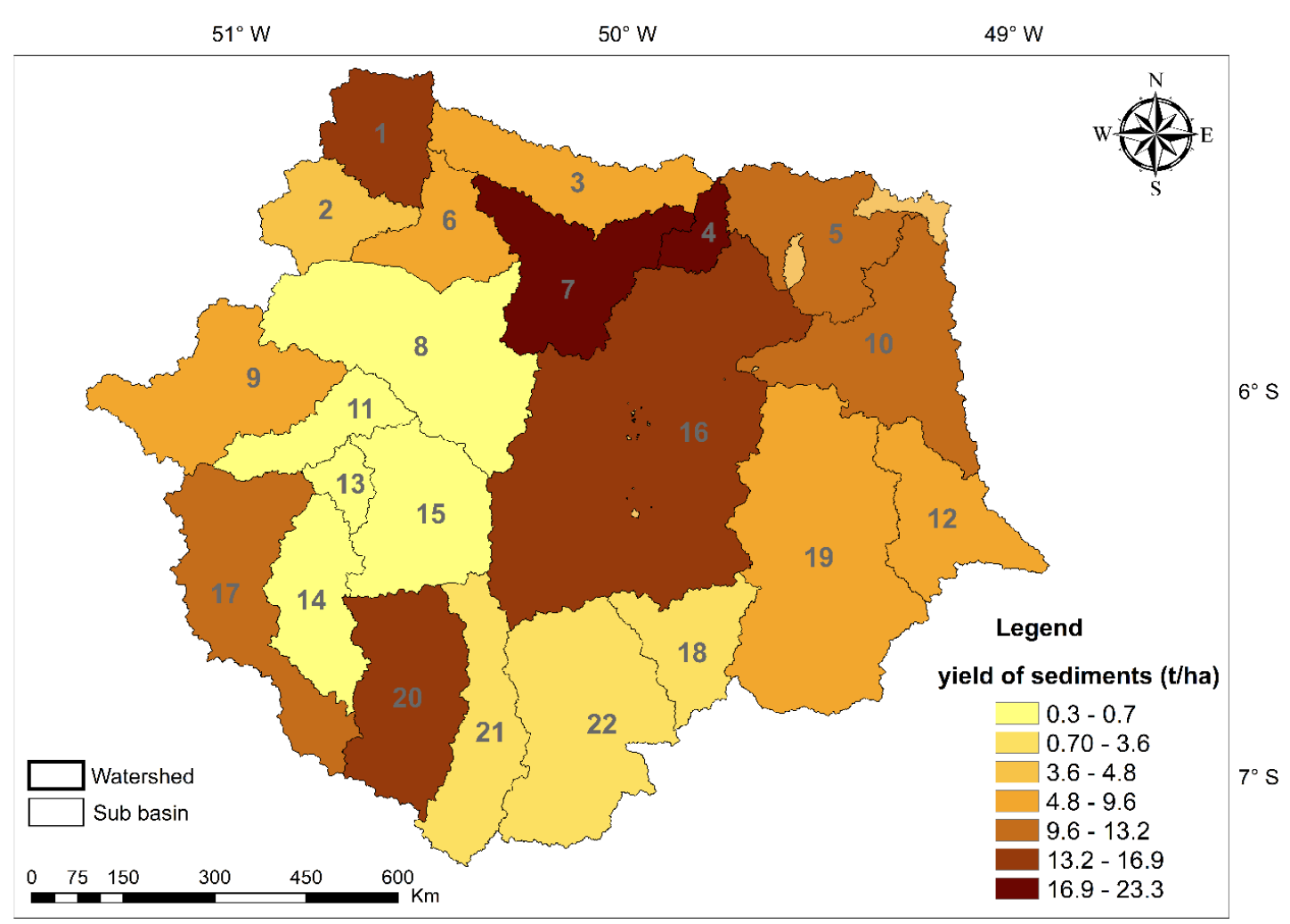

Figure 5. Spatial distribution of yield sediment by sub-basin

In this respect, the Sub basin 20 is among the sub-basins with higher sediment yield and is the basin with the least precipitation and runoff, but is among the regions of greater slope in the basin and have high land use dynamics. this respect, Machado and Vettorazzi (2003) argued that the hydrological processes associated with land use and management clearly play a dominant role in sediment production and transport. Within this subject, Martins Filho et al. (2009) asserted that the vegetation plays an important role in controlling erosion and reducing the loss of organic matter and nutrients through sedimentation. the problems caused by sediment are numerous, including siltation of rivers, increasing the magnitude of flooding, and siltation of reservoirs, diminishing their capacity and supply for irrigation, among others (Coe et al., 2011). These problems depend of the quantity and nature of the sediment that are related with the production processes (geologic formation), transportation (slope and rainfall), and deposition (depth of the riverbed).

Figure 6 shows various types of land use in the Itacaiúnas River basin and rainfall variations (P), actual evapotranspiration (ET) and runoff by sub-basin. The sub-basins with areas of forest as predominant in the use of the land have greater stability in the $\mathrm{P}$, ET and runoff variables, with the exception of sub-basin 8 , which has areas of deforestation, mining, grazing, and reforestation resulting in a greater runoff. Therefore, the hydrological processes associated with land cover and management clearly play a dominant role in sediment production and transport (Silva et al., 2018).

Analyzing the sub-basins in the east area of the forest, using the land predominantly for pasture, a contrast with the other uses of land is noticeable, particularly, regarding the runoff. In sub-basins 5,11 , and 12 , there is an increase in surface runoff at pasture areas, once this type of land usage facilitates greater surface water flow because of forest removal (Figure 7). A similar result was 
obtained by Golmohammadi et al. (2017) who assessed the capability of SWAT to identify areas contributing to runoff at the Gully Creek Watershed in Ontario, Canada.

Normally low rates of evapotranspiration are associated with the withdrawal the forest and the compacted land (normally because of low slope), and a small leaf area, like pasture. A similar result was obtained by Abiodun et al. (2018) comparing of MODIS and SWAT evapotranspiration with different land cover at different spatial scales. However, the sub-basins with the predominant forest as land use, ET is more significant. Similar results were found by Coe et al. (2011) in which the runoff increased after the simulation of the model that replaced forested areas by pasture and decreased the evapotranspiration.

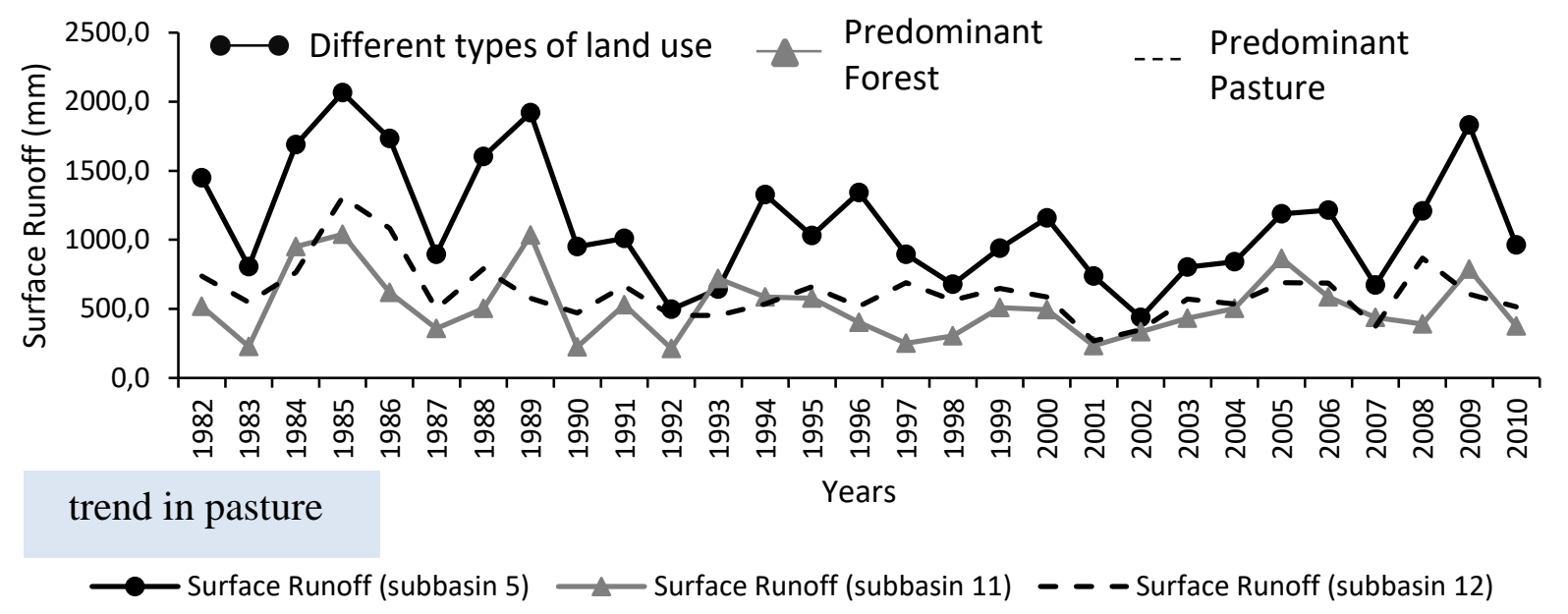

Figure 6. Relation between land use and land cover classes and water balance variables per subbasin, simulated using the SWAT model and 41 years of data.

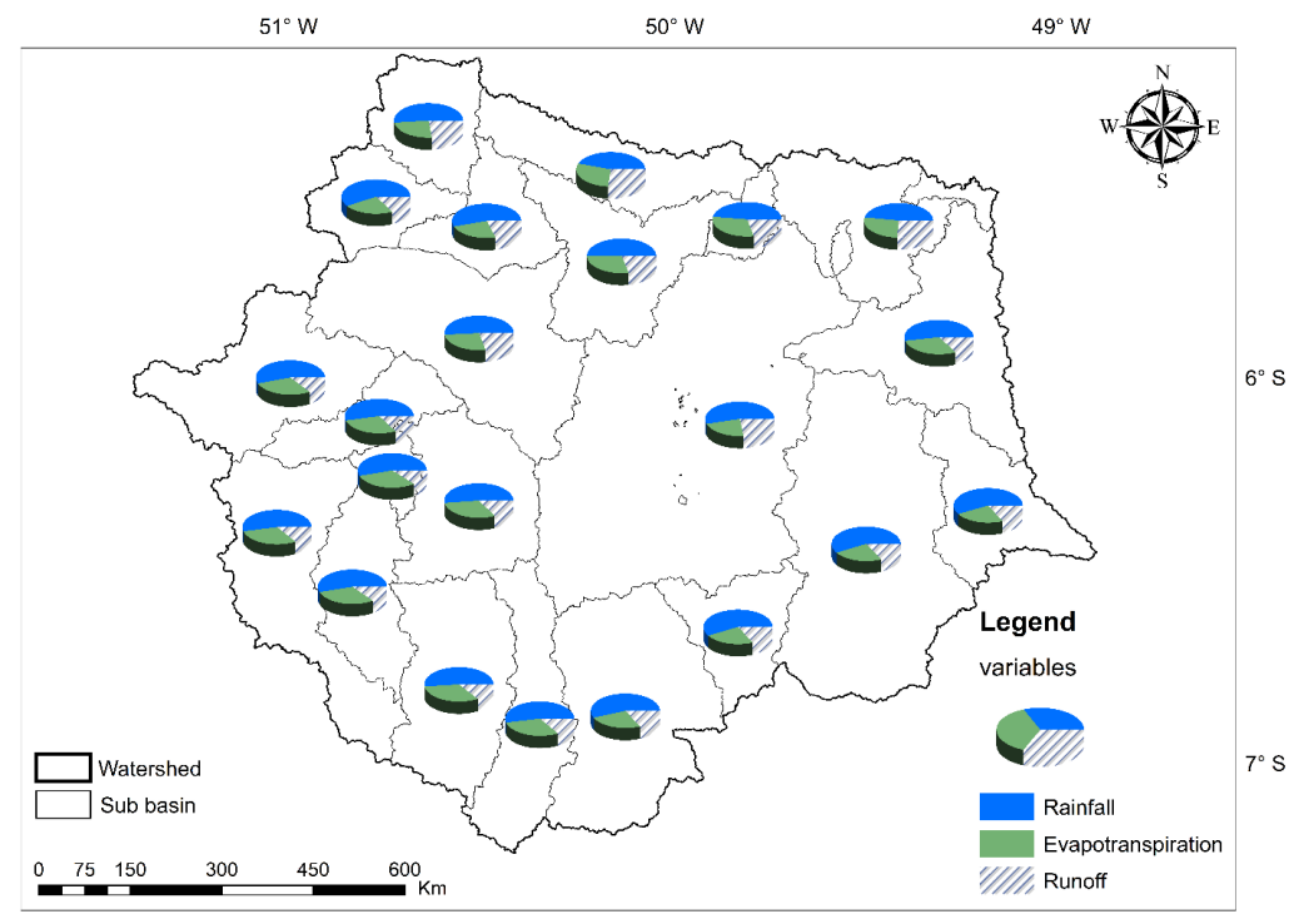

Figure 7. Runoff by land use and land cover. 
When applying the statistical tests in this series of data, the Mann-Kendall test detected that subbasins dominated by pasture tended to increase runoff. The series showed no tendency for the sub-basins that predominate the use of land as forest. Silva et al. (2017b) found a similar result when replacing native vegetation caatinga by pasture.

For the sub-basin with multiple uses of land, an anomalous result was obtained, but it was consistent with the history of the basin, as previously described, in which the runoff had a tendency to decay over the years, and it was not a homogenous series over the years, and there is a break in the mean of this variable. Chen-Feng et al. (2014) obtained a similar result for a model of river flow in Taiwan, where for areas of multiple uses of land, the flow will tend to fit the greater use shown in the area. The land cover affects sediment yield, potential evapotranspiration, and surface runoff of the basin and hence influences the water balance. Hydrologic models are essential for studying hydrologic processes and their responses to both natural and anthropogenic factors (Lironga and Jianyuna, 2012).

\subsection{Hydrological simulation (streamflow and validation)}

Figure 8 shows the annual flow (observed and simulated) during the simulation period. I 1996 the simulated flow began to underestimate the flow observed. Again, the issue of high dynamics of land use during these years can influence the downstream flow. It is seen that the land use types inserted into the model are the uses that already exist in the database of SWAT and have similarity to the current usage of the basin, creating even more uncertainties in the simulation. The change in vegetation cover in a watershed can change the water balance in the region.

Deforestation alters the porosity of the soil by pore sealing during precipitation events, changing their hydraulic properties. Deforestation also often results in increased erosion of the Earth's surface and deposition in channels and floodplains because of the increased area of bare soil, changes in infiltration and runoff and poor management practices (Bruijnzeel, 1991). Costa et al. (2003) analyzed the data and climate in a $175,000 \mathrm{~km}^{2}$ sub-basin of the basin of the Tocantins River in the eastern Amazonia and concluded that most of the observed increase of $25 \%$ in that discharge drainage basin was attributable to deforestation.

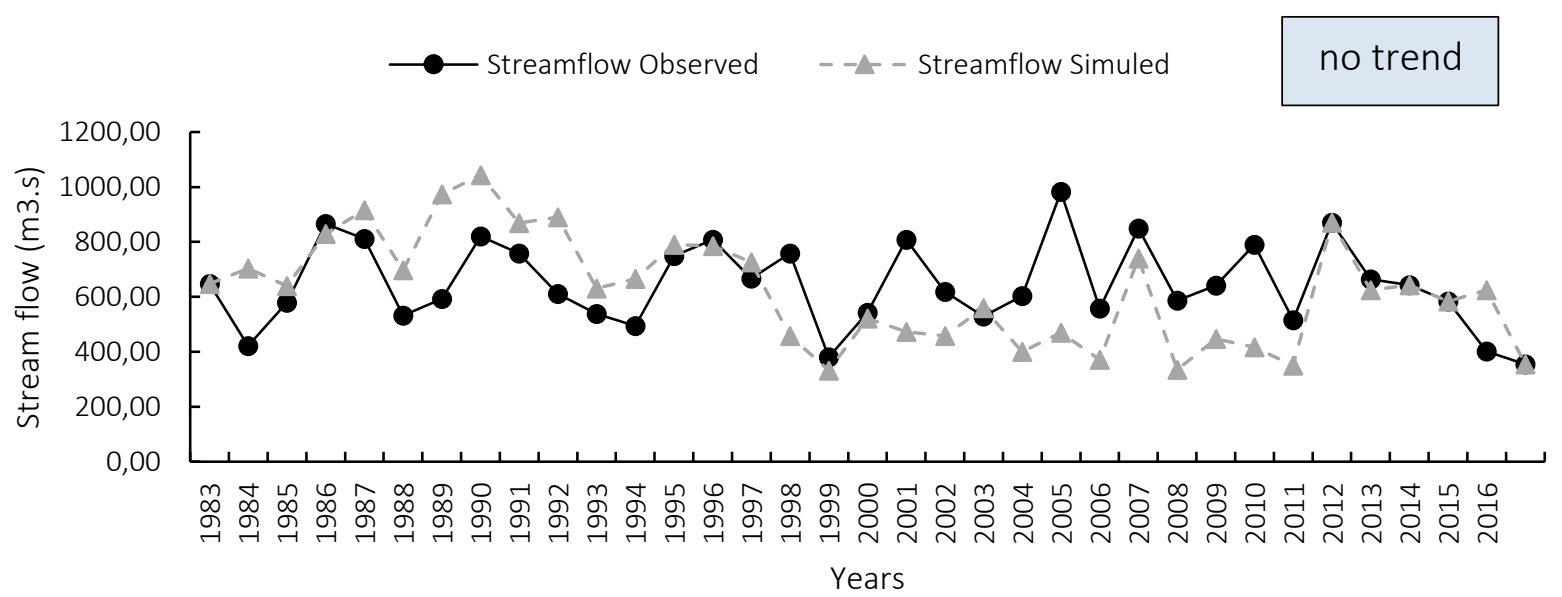

Figure 8. Observed and simulated streamflow series 
Validation of the variables simulated by SWAT flow data were used for the period 2010 to 2016 and evapotranspiration was used for weather data from Marabá and applied to the statistical indexes described in table 2. Thus, we obtained the validation of flow and evapotranspiration for the Itacaiúnas River basin. Figure 9 shows the relationship of flow observed and simulated flow, it is apparent that during some years in the simulation using SWAT some outliers occurred, in some years the model did not obtain a good simulation of the streamflow.

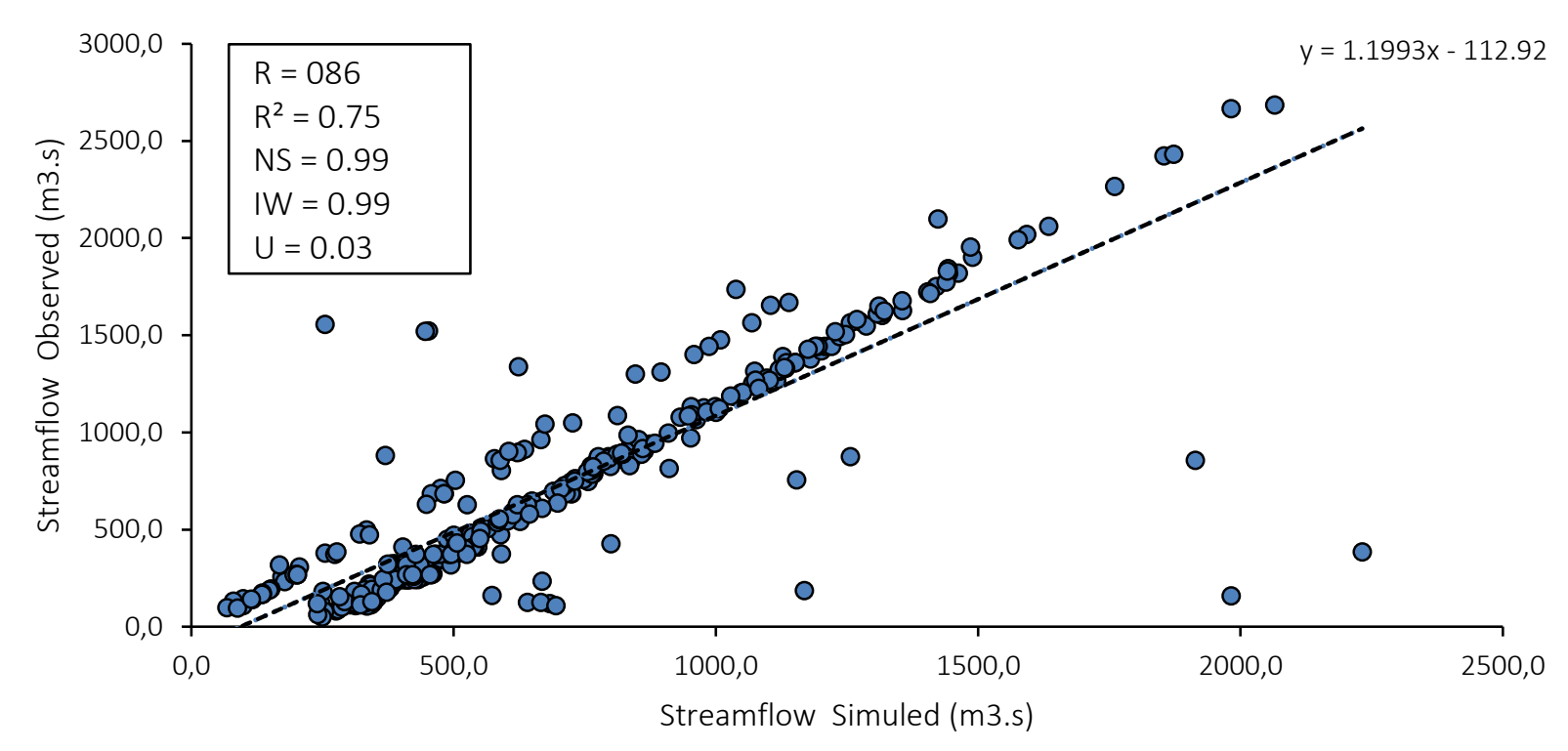

Figure 9. Relationship observed and simulated flow and validation.

Even if the model does not accurately reproduce some flow periods, statistical indices obtained satisfactory performance for the validation period, the correlation coefficient of Pearson was 0.86 and the determination was 0.74 being a good value for modeling uncertainty. For the NashSutcliffe coefficient and index of concordance of Willmott a value of 0.99 was obtained, both considered excellent by the literature. The $U$ coefficient of Theil was 0.03 , an excellent value. Finally, when applying statistical tests of trend and homogeneity in the flow and sediment series, it was observed that the two series remained without a trend and were homogeneous, thus, it is assumed that on the whole, the water is in balance, where the different types of use if the soil, slope, and soil types and finally the weather, fit.

\section{Conclusion}

The results of the SWAT land use model showed that the three main soil uses in the basin have different influences on the variables of the water regime. Pasture was assigned as the usage type that obtained the highest values of precipitation, runoff, and sediment transport. These results are of utmost importance in sustainable management of water resources in the Itacaiúnas River 
basin, because it is possible to know how the water variables are conditioned by human actions and in which rivers this is more prominent.

With the calibration of the model, it was possible to observe that some parameters are the most influential on the water than other processes, which allowed us to improve the simulation of the Itacaiúnas River basin, and thus a better model of the current scenario of the region was produced. The prevailing regions with greater slope and high dynamics of use tend to be more vulnerable to sediment transport and, consequently, the erosive process.

For validation of SWAT, all statistical indices presented showed excellent results, showing that the model is valid for the region and can be applied in other studies. The SWAT model is fully incorporated into the scientific context and has great potential to be used in river basins that are less monitored. This type of study is needed in the Brazilian Amazon, which has a low density of meteorological stations. The statistical tests of trend and homogeneity are important in understanding how variables are studied and the results are consistent with the literature.

Finally, it is understood that SWAT can be a tool for managing water resources and the environment in the Amazonian region and also serve as a basis for decision makers to improve management.

\section{AUTHOR'S CONTRIBUTION}

Definition of research problem (Edivaldo Serrão, Madson Silva and Francisco Sousa), Literature review (Edivaldo Serrão, Aline Lima and Vicente Silva), Definition of methodological procedures (Edivaldo Serrão and Madson Silva), Data collection (Edivaldo Serrão, Cleber Santos and Aline Lima ), Data processing (Lorena Ataide and Edivaldo Serrão ) Analysis and interpretation of data (Edivaldo Serrão and Madson Silva), Manuscript writing (Edivaldo Serrão, Madson Silva, Francisco Sousa and Vicente Silva) and review of writing (Aline Lima, Cleber Santos, Lorena Ataide and Vicente Silva).

\section{REFERENCES}

Abiodun, O. O., Guan, H., Post, V. E. A. and Batelaan, O. 2018. Comparison of MODIS and SWAT evapotranspiration over a complex terrain at different spatial scales, Hydrology and Earth System Sciences, 22, pp. 2775-2794.

Adam, E. D. L. and Vecchia, F. A. S. 2011. Analise de Diferentes Métodos de Interpolação para a Precipitação Pluvial no Estado de Goiás. Acta Scientiarum Human and Social Sciences, 33 (2), pp. 193-197.

Alves, D. B. and Pérez-Cabello, F. 2017. Multiple remote sensing data sources to assess spatiotemporal patterns of fire incidence over Campos Amazônicos Savanna Vegetation Enclave (Brazilian Amazon), Science of the Total Environment, 602, pp. 142-158.

Arnold, J. G. and Fohrer, N. 2005. SWAT2000: current capabilities and research opportunities in applied watershed modelling. Hydrological processes, 19(3), pp. 563-572. 
Arnold, J. G., Srinivasan, R., Muttiah, R.S. and Williams, J. R. 1998. Large area hydrologic modeling and assessment. Part I: Model development. Journal of the American Water Resources Association, 34(1), pp. 73-89.

Arnold, J. G., Moriasi, D. N., Gassman, P. W., Abbaspour, K. C., White, M. J. and Srinivasan, R. 2012. SWAT: Model use calibration and validation. Transactions of ASABE, 55(4), pp. 1494-1508.

Baker, T. J. and Miller, S. N. 2013. Using the Soil and Water Assessment Tool (SWAT) to assess land use impact on water resources in an East African watershed, Journal of Hydrology, 486, pp. 100111.

Bruijnzeel, L. A. 1991. Hydrological impacts of tropical forest conversion. Nature, 27(2), pp. 3646.

Chaves, H. M. L. 1991. Análise Global da sensibilidade dos parâmetros da equação universal de perda de solo modificada (MUSLE). Revista Brasileira de Ciência do Solo, 15, pp. 345-350.

Chaves, H. M. L and Piau, L. P. 2008. Efeito da variabilidade da precipitação pluvial e do uso e manejo do solo sobre o escoamento superficial e o aporte de sedimento de uma bacia hidrográfica do Distrito Federal. Revista Brasileira de Ciência do Solo, 32(1), pp. 333-343.

Chen, J. L., Wilson, C. R., and Tapley, B. D. 2010. The 2009 exceptional Amazon flood and interannual terrestrial water storage change observed by grace. Water Resources Research, 46, pp. 1-10.

Chen-Feng, Yeh., Jinge, Wang., Hsin-Fu, Yeh. and Cheng-Haw, Lee. 2014. Spatial and Temporal Streamflow Trends in Northern Taiwan. WATER, 7(2), pp. 634-651.

Coe, M. T., Costa, M. H. and Soares Filho, B. S. 2009. The influence of historical and potential future deforestation on the stream flow of the Amazon River - Land surface processes and atmospheric feedbacks. Journal of hydrology, 369, (1-2), pp. 165-174.

Coe, M. T., Latrubesse, E. M., Ferreira, M. E. and Amsler, M. L. 2011. The effects of deforestation and climate variability on the streamflow of the Araguaia River, Brazil. Biogeochemistry, 105(1-3), pp. 119-131.

Costa, M. H., Botta, A. and Cardille, J. A. 2003. Effects of large-scale changes in land cover on the discharge of the Tocantins River, Southeastern Amazonia. Journal of Hydrology, 283(1-4), pp. 206-217.

Golmohammadi, R., Rudra, R., Dickinson, T., Goel, P. and Veliz, P. 2017. Predicting the temporal variation of flow contributing areas using SWAT. Journal of Hydrology, 547, pp. 375-386.

Hallak, R. and Pereira Filho, A. J. 2011. Metodologia para Análise de Desempenho de Simulações de Sistemas Convectivos na Região Metropolitana de São Paulo com o Modelo ARPS: Sensibilidade a Variações com os Esquemas de Adveç̧ão e Assimilação de Dados. Revista Brasileira de Meteorologia, 26(4), pp. 591-608.

INPE - INSTITUTO NACIONAL DE PESQUISAS ESPACIAIS. 2012. Projeto PRODES: Monitoramento da Floresta Amazônica Brasileira por Satélite. 2012. Available at: < http://www.obt.inpe.br/OBT/assuntos/programas/amazonia/prodes >. [Accessed 05 May 2017].

Lironga, S. and Jianyuna, Z. 2012. Hydrological response to climate change in Beijiang River Basin based on the SWAT model, Procedia Eng, 28, pp. 241-245.

Liu, Z., Ostrenga, D., Teng, W. L. and Kempler, S. J. 2013. Implementing the International Precipitation Working Group (IPWG) Validation Statistics in Online Tools to Inter-compare and 
Characterize Satellite-derived Global Precipitation Products, American Geophysical Union, Fall Meeting, San Francisco.

Machado, R. E. and Vettorazzi, C. A. 2003. Simulação da produção de sedimentos para a microbacia hidrográfica do ribeirão dos Marins, SP. Revista Brasileira de Ciência do Solo, 4, pp. 735-741.

Machado, R. E., Vettorazzi, C. A. and Xavier, A. C. 2003b. Simulação de cenários alternativos de uso da terra em uma microbacia utilizando técnicas de modelagem e geoprocessamento. Revista Brasileira de Ciência do Solo, 27(4), pp. 727-733.

Malhi, Y. J., Roberts, T., Betts, R. A., Killeen, T. J., Li, W. and Nobre, C. A. 2008. Climate change, deforestation, and the fate of the Amazon. Science, 319(4), pp. 169-172.

Marengo, J. A., Nobre. C., Tomasella, J., Oyama, M., Oliveira, G. S., Oliveira, R., Camargo, H., Alves, L. M. and Brown, I. F. 2008. The drought of Amazônia in 2005. Journal of Climate, 21(2), pp. 495516.

Martins Filho, M. V., Licciotl, T. T., Pereira, G. T., Marques Júnior, J. and Sanchez, R. B. 2009. Perdas de solo e nutrientes por erosão num Argissolo com resíduos vegetais de cana-deaçúcar. Engenharia Agrícola, 29, pp. 8-18.

Neitsch, S. L., Arnold, J. R., Kiniry, J. R. and Williams, J.J. 2005. Soil and water assessment tool: theoretical documentation - version 2005. SERVICE., G-S. A. W. R. L. - A. R. Texas USA.

Neitsch, S. L., Arnold, J. G., Kiniry, J.R. and Williams, J.R. 2011 Soil and Water Assessment Tool. Theoretical documentation version 2009. Temple, Blackland Research Center, Texas Agricultural Experiment Station.

Nunes, J. G., Campos, M. C. C., Oliveira, F. P. and Nunes, J. C. 2012. Tolerância de perda de solo por erosão na região sul do Amazonas. Ambiência Guarapuava (PR), 8(3), pp. 859-868.

Sahin, V. and Hall, M. J. 1996. The effects of afforestation and deforestation on water yields. Journal of Hydrology, 178(1-4), pp. 293-309.

Santos, R. S., Costa, L. C., Sediyama, G. C., Leal, B.G., Oliveira, R. A. and Justino, F. B. 2011. Avaliação da relação seca/produtividade agrícola em cenário de mudanças climáticas. Revista Brasileira de Meteorologia, 26, pp. 313-321.

Scanlon, B. R., Jolly, I., Sophocleous, M. and Zhang, L. 2007. Global impacts of conversions from natural to agricultural ecosystems on water resources: quantity versus quality. Water Resources Research, 43(3), pp. 1-18.

Serrão, E. A. O., Wanzeler, R. T. S., Santos, C. A., Gonçalves, L. J. M., Lima, A. M. M. and Rocha, E. J. P. 2016. Avaliação Estatística entre as Estimativas de Precipitação da Constelação GPM com TRMM: Uma Análise a Bacia Hidrográfica do Rio Solimões. Revista Brasileira de Climatologia, 18, pp. 256-275.

Schuol, J., Abbaspour, K. C., Srinivasan, R. and Yang, H. 2008. Estimation of freshwater availability in the West African sub-continent using the SWAT hydrologic model. Journal of Hydrology, 352(1), pp. 30-49.

Silva, M. T., Silva, V. P. R., Souza, E. P. and Araújo, A. L. 2015. Aplicação do modelo SWAT na estimativa da vazão na bacia hidrográfica do submédio rio São Francisco. Revista Brasileira de Geografia Física, 08(06), pp. 1615-1627. 
Silva, V. P. R., Silva, M. T. and Souza, E. P. 2016. Influence of land use change on sediment yield: a case study of the sub-middle of the são francisco river basin. Engenharia Agrícola, 36(06), pp. 1005-1015.

Silva, V. P. R., Silva, M. T., Braga, C.C., Singh, V. P., Souza, E. P., Sousa, F. A. S., Holanda, R. M., Almeida, R. S. R. and Braga, A. C. R. 2017 b. Simulation of stream flow and hydrological response to land-cover changes in a tropical river basin. Catena, 162, pp. 166-176.

Silva, M. T., Azevedo, P. V., Silva, V. P. R., Silva, B. K. N., Mariano, E. B. and AMORIN, M. R. B. 2017 A. Estimate the sediment yield in the basin of lower-middle São Francisco River. Journal of Environmental Analysis and Progress, 02(02), pp. 203-211.

Stickler, C. M., Coe, B. M. T., Costac, M. H., Nepstada, D. C., McGrath, D. G., Dias, L. C. P., Rodrigues, H. O. and Soares Filho, B. S. 2013. Dependence of hydropower energy generation on forests in the Amazon Basin at local and regional scales. Proceedings of the National Academy of Sciences, 110(23), pp. 9601-9606.

Theil, H. 1966. Applied Economic Forecasting. 1nd ed. Amsterdam, Netherlands, North-Holland.

Tomasella, J., Borma, L. S., Marengo, J. A., Rodriguez, D. A., Cuartas, L. A., Nobre, C. A. and Prado, M. C. R. 2010. The droughts of 1996-1997 and 2004-2005 in Amazonia: Hydrological response in the river main-stem. Hydrology Processes, 25. pp.1228-1242.

Trigg, M. A., Wilson, M. D., Bates, P. D., Horritt, M. S., Alsdorf, D. E., Forsberg, B. R. and Vega, M. C. 2009. Amazon flood wave hydraulics, Journal of Hydrology, 374, pp. 92-105.

Tucci, C. E. M. 2005. Modelos Hidrológicos. Editora da Universidade Federal do Rio Grande do Sul - ABRH. 2ed. Porto Alegre.

Tucci, C. E. M. 2009. Hidrologia: Ciência e aplicação. Editora da Universidade Federal do Rio Grande do Sul - ABRH. 4ed. Porto Alegre.

Wagener, T. and Montanari, A. 2011. Convergence of approaches toward reducing uncertainty in predictions in ungauged basins. Water Resources Research, 47(6), pp. 1-8.

Willmott, C. J., Ckleson, S. G. and Davis, R. E. 1985. Statistics for evaluation and comparisons of models. Journal of Geophysical Research, 90(5), pp. 8995-9005.

Winchel, M., Srinivasan, R., Di Luzio, M. and Arnold, J. 2013. ArcSWAT Interface for SWAT 2012: User's Guide. Texas, USA: Texas AgriLife Research, USDA Agricultural Research Service.

Zhang, P., Liu, Y. and Pan, Y., Yu, Z. 2013. Land use pattern optimization based on CLUE-S and SWAT models for agricultural non-point source pollution control. Mathematical and Computer Modelling, 58(3), pp. 588-595. 